\title{
Impact of green revolution on rice cultivation practices and production system: A case study in Sindang Hamlet, Rancakalong Village, Sumedang District, West Java, Indonesia
}

\author{
RAHMI AULIA HIDAYAT ${ }^{1}$, JOHAN ISKANDAR ${ }^{2}$, BUDHI GUNAWAN ${ }^{3}$, RUHYAT PARTASASMITA ${ }^{2, \bullet}$ \\ ${ }^{1}$ Graduate Program in Environmental Science (PSMIL), Universitas Padjadjaran. Jl. Sekeloa Selatan I, Bandung 40132, West Java, Indonesia \\ ${ }^{2}$ Department of Biology, Faculty of Mathematics and Natural Sciences, Universitas Padjajaran. J1. Raya Bandung-Sumedang Km 21, Jatinangor, \\ Sumedang 45363, West Java, Indonesia. Tel.: +62-22-7797712, Fax. +62-22-7794545."email: rp2010rikkyo@ gmail.com; ruhyat.partasasmita@unpad.ac.id \\ ${ }^{3}$ Department of Anthropology, Faculty of Social and Political Sciences, Universitas Padjadjaran. Jl. Raya Bandung-Sumedang Km 21, Jatinangor, \\ Sumedang 45363, West Java, Indonesia
}

Manuscript received: 14 January 2020. Revision accepted: 28 February 2020.

\begin{abstract}
Hidayat RA, Iskandar J, Gunawan B, Partasasmita R. 2020. Impact of green revolution on rice cultivation practices and production system: A case study in Sindang Hamlet, Rancakalong Village, Sumedang District, West Java, Indonesia. Biodiversitas 21: 1258-1265. In the past, farmers of Sindang Hamlet, Rancakalong Village, West Java practiced the wet-rice (sawah) farming system based on the Traditional Ecological Knowledge (TEK) and belief system. They coordinate their planting schedule according to indigenous calendar known as kalender tani or pranata mangsa (Javanese). The various inputs of the sawah farming system, namely rice seeds, organic fertilizers, and pesticides intensively used originate from the village, made little use of farm supplies obtained through purchased from outside (market). In the early 1970s, the Government of the Republic of Indonesia introduced the Green Revolution to increase the rice production of the wet-rice farming system. The five-farming effort (panca usaha tani) programs, namely the use of the High Yielding Rice Varieties (HYVs), the provision for inorganic chemical fertilizers, the use of synthetic pesticides, the development and improvement of irrigation, and the improvement of methods of rice planting methods were intensively implemented. About ten years later, in 1980s, the sawah farmers of Rancakalong Village, Sumedang District, West Java have adopted the Green Revolution program. As a result, the traditional the wet-rice cultivation practices of Rancakalong farmers that was originally based on the low-external inputs has dramatically changed to the high-external-input agriculture, depending more on artificial inputs, such as inorganic fertilizers, pesticides, fossil energy, and modern rice seeds, which originate from outside of the village and generally have to be purchased. The aim of this study is to document and analyze the changing cultivation practices of the wet-rice farming systems, and rice production systems. Study was undertaken in Sindang Hamlet, Rancakalong Village, Sumedang District, West Java. Method applied in this study was a mixed-method, combination of qualitative and quantitative techniques, including observation, semistructured interviews, and structured interviews applied to 64 respondents. The result of the study showed that the farmers have stopped their traditional cyclical planting schedule based on kalender tani, most local rice varieties have been replaced by the superior or High Yielding Rice Varieties (HYVs), and farmers have become dependent on external inputs, namely inorganic fertilizers, synthetic fertilizers, modern rice seeds, and fossil energy. Consequently, the HYVs have also more vulnerable to diseases and pests, such as brown plant-hopper (Nilarparvata lugens Stal), and also vulnerable to scarcity of water due to drought caused by climate change. This study stresses that a model agriculture system that is ecologically sound, economically viable, and adaptable must be undertaken to develop sustainable agriculture.
\end{abstract}

Keywords: Green revolution, production system, sustainable agriculture, wet-rice farming system

\section{INTRODUCTION}

Farmers in rural areas manage their farming activities based generally on traditional ecological knowledge. Traditional ecological knowledge is a unique local knowledge system produced by a culture or society, in contrast to international scientific systems or Western scientific knowledge generated through a global network of universities and research institutions (Warren et al. 1995; Ellen and Harris 2000). This knowledge makes the practice of cultivation is still dependent on environment and natural materials as inputs, as well as the use of traditional agricultural dating as guidelines for rice cultivation activities. The method followed by these farmers tends to be sustainable because of minimum input of synthetic chemicals.
Over time, the practice of community rice management has changed. In the early 1960s, Indonesia became one of the largest rice importing countries in the world. Indonesia's national economy at that time was in bad condition. The exchange rate of the rupiah against the dollar had fallen sharply. Large rice imports also affected the country's reduced foreign exchange. The exchange rate of the rupiah per US dollar was Rp. 186.67, in 1961, and increased sharply in 1965 to Rp.14,083, per US dollar (Prawiro 1998). Meanwhile, local rice production was not able to meet the country's food needs. In 1967, when President Suharto was serving the Republic of Indonesia, the first step taken by him was to increase rice production. Rice self-sufficiency was one of Indonesia's later economic targets. 
Farmers in rural West Java practice paddy farming based on traditional ecological knowledge (Partasasmita et al. 2019). Traditional ecological knowledge can be defined as a cumulative body of knowledge, practice, belief about the relationship of living beings (including humans) with one another and with their environment, evolving by adaptive processes and handed down to generations by cultural transmission, (Warren et al. 1995; Berkes 1999; Ellen and Harris 2000).

The much-needed increase in rice production was realized by the Green Revolution Program. This program generally aims to change the level of production of green plants or food crops simultaneously. The approach to Green Revolution was agricultural intensification, including the use of synthetic fertilizers, introduction of new high yielding rice cultivars, use of agricultural processing machines, monoculture cultivation, control of weeds, pests and diseases using synthetic pesticides, land expansion, and irrigation network intensification (Gliessman 2007). Superior rice seeds are introduced to replace local rice, which shortened the harvest period (3-4 months). Local rice takes 5-6 months to be harvested (Partasasmita et al. 2019).

All these improved rice cultivations in Indonesia, achieving self-sufficiency in rice production. However, the green revolution program, on the other hand, caused brown plant hopper pest explosion (Nilarparvata lugens Stal) and decreased production in 1986, a year after the FAO awarded President Soeharto because he had achieved "rice self-sufficiency". At that time, Presidential Instruction No.3/1986 imposed a ban on 57 broad-spectrum insecticide products (organophosphates), and the launching of the National Integrated Pest Management Program. Surprisingly, two decades later there was a pest explosion again, precisely in 2009-2011. The study of entomologists proved that excessive and unwise use of chemical pesticides was the cause of brown planthopper when environmental conditions are conducive to increase pest populations (Winarto and Yunita 2016).

In addition to explosion of pests, changes in paddy management also lead to reduced water availability, as well as a decline in the diversity of local rice cultivars (Iskandar et al. 2018). Economically, input from outside (made by the factory) created dependency on the community and decreased independence in farming. A study related to the management of paddy fields in Sindang Village, Rancakalong Village, which was previously conducted by Warsiti (2009), proved the decline in local rice cultivars from the previous year. Further research related to the system of cultivation and production of paddy in the Sindang Hamlet community will be interesting. This study was undertaken to compare the input and output of rice farming before and after the Green Revolution, to compare local and improved rice production, to analyses rice production based on land area, and to assess the impact of changes in rice cultivation in Sindang Hamlet.

\section{Study site}

This research was conducted in Sindang Hamlet, Rancakalong Village, Rancakalong District, Sumedang Regency, West Java Province, Indonesia. The distance from Rancakalong Village to Sumedang District is $14 \mathrm{~km}$, while Bandung City is $45 \mathrm{~km}$. Average altitude of Rancakalong Village is $700 \mathrm{~m}$ above sea level, the average annual rainfall is $1500-3000 \mathrm{~mm}$, and the average temperature is $22^{\circ} \mathrm{C}$. Rancakalong Village has an area of $325 \mathrm{~km}^{2}, 155,784 \mathrm{~km}^{2}$ of rice field, $229,216 \mathrm{~km}^{2}$ of land, located at latitudes $6^{\circ} 50^{\prime} 082.2 \quad$ "S-107 $57^{\circ} 12.6$ E. Rancakalong Village is bounded by Cibunar Village and Nagarawangi Village in the north, Pasirbiru Village in the south, Cijambu Village in the west, and Pamekaran Village in the east. There are 3 hamlets, $8 \mathrm{RW}, 36 \mathrm{RT}$, the number of $\mathrm{KK}$ (Households/HH) is 1859 , with a total population of 5004 inhabitants. The three hamlets are, Rancakalong Hamlet, Pasir Hamlet, and Sindang Hamlet. Sindang Hamlet has 598 households in 2019 (Profile of Rancakalong Village 2019). This research was conducted only in Sindang Hamlet, which was previously known to have the largest number of farmers growing local rice from other hamlets $(194 \mathrm{HH})$ out of $529 \mathrm{HH}$ in Rancakalong Village, and the diversity of local rice totaling 22 cultivars (Warsiti 2009). Livelihood of most of the population is farming. Crops commonly planted are rice, hui Cilembu (sweet potato Cilembu), corn, tobacco, and vegetables such as cabbage, chili, and tomato. There are two types of rice fields in Rancakalong Village, namely ledok rice field (high water content field) and cengkar rice field (medium water level rice field).

\section{Procedure}

A mix of both qualitative and quantitative methods with an ethnoecological approach was used with emphasis on the process of changes pertaining to paddy field management system (Newing et al. 2011; Albuquerque et al. 2014; Iskandar and Iskandar 2016; Iskandar 2018). The techniques for collecting field data were observation, participatory observation, semi-structured (deep interviews) and structured interviews. The general environmental conditions of the agroecosystem types, including the wet rice field (sawah) system, was recorded by observation. The participatory observation was by both asking and participating in some activities of local informants related to wet rice farming systems, including planting, harvesting, and also in the traditional rituals after harvesting rice. Semi-structured interviews (deep interviews) were conducted with 10 informants who are considered competently related to changes in rice management systems in Sindang Hamlet. The informants were chosen purposively based on their respective expertise. Deep interviews were carried out using interview guidelines that had been prepared previously related to changes in the paddy management system in Sindang Hamlet. 


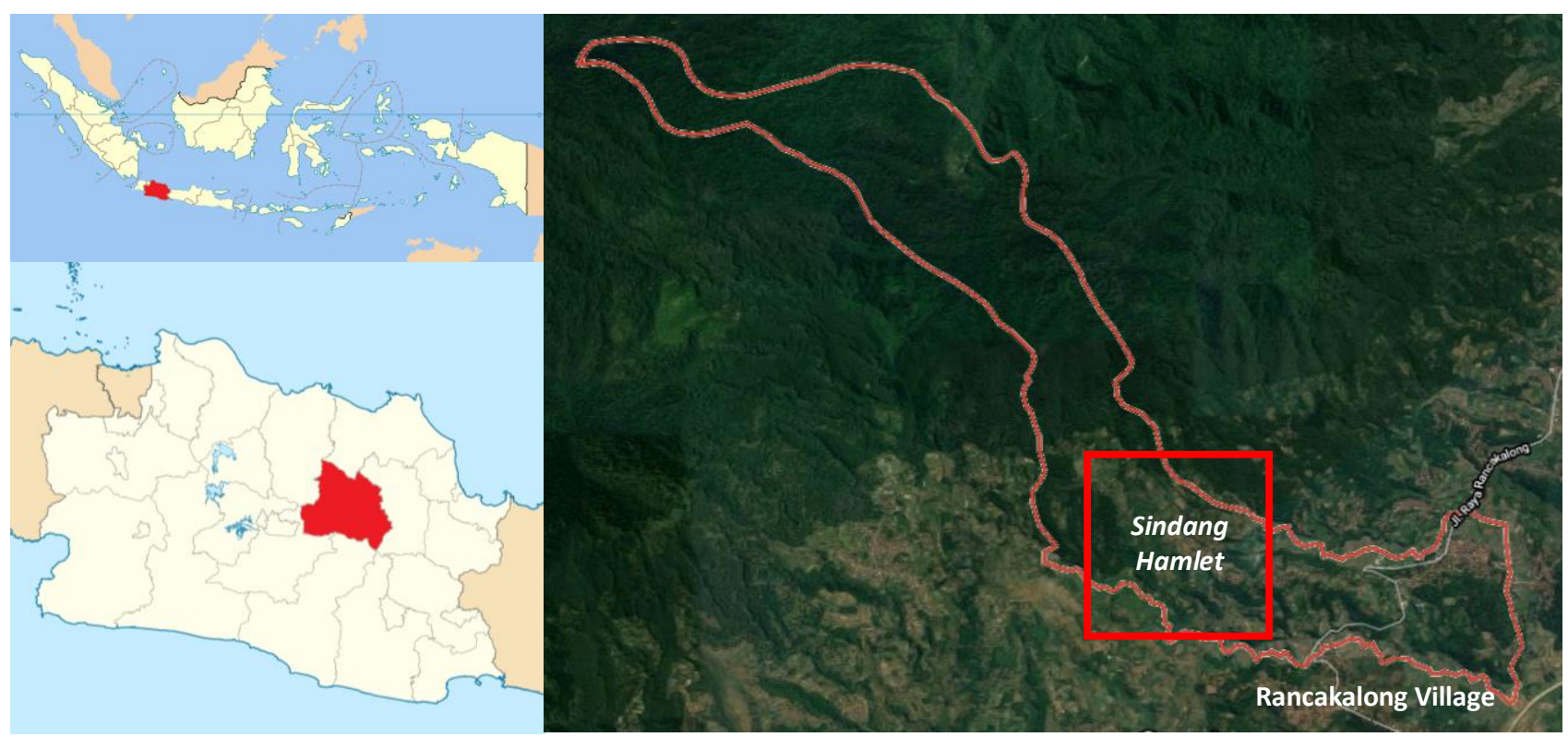

Figure 1. Location of study in Sindang Hamlet, Rancakalong Village, Sumedang District, West Java, Indonesia

\section{Data analysis}

Data analysis was carried out by cross-checking, summarizing and synthetizing data gathered by various methods, namely semi-structured interviews, structured interview, participatory observations, and secondary data, which were made into a descriptive narrative containing changes in rice management including the local rice cultivars still planted today, how farmers carry out paddy management and rituals related to agricultural management in Sindang Hamlet, Rancakalong Village. After knowing the changes, an analysis of the impact of change in economic and ecological aspects was also carried out. Meanwhile, to see the sustainability of farming in terms of production, R/C analysis was conducted which compares the income from rice fields with the inputs provided.

\section{RESULTS AND DISCUSSION}

Rancakalong Village consists of three hamlets, namely Sindang Hamlet, Pasir Hamlet, and Rancakalong Hamlet. This study was conducted only in Sindang Hamlet because it is known as a hamlet having the highest diversity of local rice (Warsiti 2009). The number of farming households in Sindang Hamlet was 196. Based on Lynch et al. (1974) formula, 64 households were selected as informants. Out of these 64 respondents, 54 of the respondents have rice fields, while 10 households are laborers in rice fields (derep). Before the green revolution, the whole community planted local rice (pare jangkung/pare buhun). After the green revolution, the government recommended planting superior rice cultivars (pare pendek/ superior rice). Many people in Sindang Hamlet started trying to plant superior rice cultivars around the 1990s.

After the green revolution, were 22 local rice cultivars left in the Sindang Hamlet (Warsiti 2009). According to
Sastrapraja et al. (1989), germplasm erosion of both local rice cultivars and other plant species is a cause for concern because it can have both social and ecological impacts. In this paper, we will discuss four such issues, namely the comparison of local rice production with superior rice, comparison of rice production before and after green revolution, comparison of production based on the area of paddy fields, and the impact of changes in rice farming practices.

\section{Comparison of rice production before and after the green revolution}

In terms of cropping systems in Sindang Hamlet, rice planting in fields was carried out simultaneously, before green revolution. This minimizes the menace of pests like birds. But, after the Green Revolution, the planting time of each farmer is different and they usually tend to overtake each other, which is ensuring availability of food always to birds and other pests. As a consequence, in addition to birds, others like rats and planthoppers also attack rice fields.

Before the Green Revolution, people used natural signs as a guide in farming. These natural signs can be in the form of animals and plants that indicate the change of seasons, such as bamboo leaves (Gigantochloa apus) $\mathrm{t}$ becoming reddish (merang), blooming of lilies and flies entering the house, all indicating the arrival of rainy season. Meanwhile, the dry season is marked by drying and shedding of fruits by cottonwood tree (Ceiba pentandra) and the emergence of the star of the kidang (The belt of orion).

All farmers in Sindang Hamlet no longer use the traditional agricultural calendar. However, $37 \%$ of farmers have knowledge about the right months for planting and harvesting, and have knowledge related to the change of seasons. They believe that the best month for planting in 
the rainy season (ngijihkeun) is the 12th month (Silih mulud), whereas in the dry season (ngatigakeun) 5th month (Fasting) or $6^{\text {th }}$ month (Shawwal) is most ideal. The best days for rice harvest, according to farmers in Sindang Hamlet, are Thursday and Saturday. Farmers are also familiar with a number of restrictions related to their rice field farming, such as abstinence from grinding rice on Saturdays and abstinence from planting on Tuesday, Friday and Monday. The locals believed that if these restrictions are violated, their land may be attacked by pests and the crops may suffer from losses.

Determination of the time to start planting is highly dependent on the availability of water. Farmers who have land close to water sources enjoy more freedom to determine their rice planting time. On the contrary, farmers whose land is quite far from the springs, have to wait for the onset of rain and the availability of sufficient water to start planting. Rice fields in Sindang Hamlet are irrigated by Walih Ciherang which forms a barrier between Rancakalong and Pasirbiru Villages. Farmers pay irrigation fees only in the dry season (ngatigakeun) usually with 2 liters of rice to the Walker (the person who regulates the water flow). Meanwhile, water for drinking and other domestic needs comes from Ciembeng Spring, which is subjected to a tariff of Rp. 10,000.00/house. Details about the input and output of paddy fields before and after the Green Revolution are summarized in Table 1.

Regarding rice cultivars that were planted, almost all farmers in Sindang Hamlet all planted local rice cultivars. They collect the seeds from the previous harvest are exchanged with family and neighbors. This is due to the fact that local rice grown during this season can only be harvested after 6 months, so that the next harvest season can be exchanged. awhile, after the Green Revolution, superior (High Yielding Improved Varieties) rice cultivars began to be widely planted, but there are still many people who grow local rice. Superior rice cultivar seeds can be planted directly in the next season, without waiting for 6 months.

Fertilizers used by the community before the Green Revolution were mostly drums from cow and goat manure. Meanwhile, in the 1980s when the Green Revolution was implemented, it was very easy to get urea fertilizer into the village as well as the Sindang Hamlet. Farmers preferred to use urea and NPK fertilizer because it is easy to obtain and to use. At present, there are many farmers in Sindang Hamlet who have livestock, but it is easier to use synthetic fertilizers than the hassle of bringing their livestock manure into the fields. After farmers in Sindang Hamlet changed to synthetic fertilizers at the beginning of the Green Revolution in 1990, usually, only $25 \mathrm{~kg}$ was used for every 100 bata $\left(1\right.$ bata $\left.=14 \mathrm{~m}^{2}\right)$ of land. However, at this time about 20 years later, it takes $30-40 \mathrm{~kg}$ of fertilizer for every 100 bata. This means that the need for rice will increase from the previous dose. In addition to using livestock manure, farmers use kirinyuh leaves (Chromolaena odorata) that are pounded and mixed with water to spread to the seedling.

Weeding is done by farmers of the Sindang Hamlet using hands (manual) and tools looking like porcupines (gasrok). At present, there are still many people who use manual methods for weeding, but some farmers additionally use Ariplus, a type of herbicide, to make the water hyacinth wilt. The day before weeding. Herbicides are given to pests, which are discarded the next day.

Rice processing equipment used before the green revolution took the form of hoes and cows. After the Green Revolution hoe was still used by farmers, but cattle were only raised for sale and then sold without being employed to plow the fields. After the Green Revolution, farmers started to use tractors that are usually leased by the people who owned them. The current rental price is around Rp.400,000.00 per 100 bata. Farmers who use tractors usually have more than 100 bata of land. Meanwhile, farmers with an area of fewer than 100 bata usually use only a hoe because the land area is not likely to use a tractor.

Before the Green Revolution, farmers processed grains using lisung by pounding (ditebek/ditutu), or by using gintiran, a kind of manual grinding tool. After the Green Revolution, farmers are processing rice using a huller (rice grinder) which is owned by only a few farmers, so other farmers hired this tool to process their grain. For processing, farmers are charged Rp. 600/kg or 1 liter for every 10 kilos of rice they get. Taxes on farmers' paddy fields are felt to be increasing year by year. One informant stated that about 15 years ago his paddy tax was only Rp.30,000.00/100 bata, now it is Rp.100,000.00Rp.150,000.00/100 bata.

Table 1 explains that the management of rice fields before the Green Revolution had very little external input. The community utilized what they have, and materials provided locally by nature to manage their rice fields. However, the current paddy cultivation system is highly dependent on external inputs because it is considered more practical. When viewed ecologically, the increasing external inputs have many negative impacts, especially on the condition of the soil, water and fauna of the paddy ecosystem (Reijntjes et al. 1992; Shiva 2016).

\section{Comparison of local rice production and superior rice production}

Farmer respondents in Sindang hamlet consisted of three groups. As many as $42 \%$ of respondents were farmers who still planted only local rice, $18 \%$ farmers planted only superior rice, and farmers who still planted both local rice and hybrid rice were $39 \%$. Local rice cultivars that are still cultivated in Sindang Hamlet include Mesir, Omas, Rayot, Mataram, Segon bereum, and Ketan randa kaya (Figure 2). Local rice cultivars can be harvested within 5 months. Meanwhile, superior rice cultivars that are now widely planted by farmers in Sindang Hamlet are Midas, Jalur and Muskem. Unlike superior rice cultivars in general that can be harvested 90-100 days (about 3 months), these rice cultivars have a crop duration of 4 months, which is almost the same as local rice planted twice each year. Fallow period lasts for about one to two months during which the seeds are made ready. The age of both seeds is the same, which is 30 days. Midas and Jalur rice have been planted by the Sindang Hamlet community in the past 5 years. 
Local rice is often called pare jangkung (tall rice) because it has a height of about $1.5 \mathrm{~m}$, while hybrid rice is called pare pendek (short rice) because it has a height of only about $50 \mathrm{~cm}$. Superior rice that is now planted by farmers in Sindang Hamlet is often called pare sedeng (average rice) because its height is not too short and not too high, and is around $70-80 \mathrm{~cm}$, or it is also called semisuperior rice.

There are several reasons that make farmers continue to grow local rice or move to superior (semi-superior) rice. Main reason to continue cultivation of local rice is that local rice is tastier. In addition, the local rice is more suitable to the land, and feels more profitable economically because of the higher paddy size and large quantity of grain. Meanwhile, the main reasons for farmers who shift to planting of superior rice include influence of friends or children who have planted superior rice (society pressure), and faster harvest (once in every 4 months). To compare inputs and outputs in the paddy farming system by planting local rice varieties and superior rice varieties can be shown in Table 2.
From Table 2 it can be seen that there are input similarities between the paddy farming based on planting local rice varieties and superior rice varieties today. Both planting local and superior rice varieties use synthetic fertilizers, such as urea and NPK. The amount of usage depends on the farmers concerned. However, there are still some respondents who use biopesticides, including Surian leaves (Toona sureni (Blume) Merr.) in rat holes. The synthetic pesticides, such as kolerat also used to eradicate rat pests. Weeding is still done by hand and also by using herbicides. Local rice and superior rice varieties are both harvested using sickles, only certain local rice varieties whose stems are hard, like ketan randa kaya, are still harvested using ani-ani (etem) until now. After the grain is obtained, both local and superior rice are processed using hullers. The use of the wood mortar (lisung or gintiran) is now very rare. Taxes on local paddy fields and superior rice are also the same, the amount charged depends on the location of paddy fields (agricultural block).

Table 1. Comparison of inputs and outputs to rice farming, before and after the green revolution

\begin{tabular}{|c|c|c|c|c|}
\hline \multirow[b]{2}{*}{ Rice cultivars } & \multicolumn{2}{|c|}{ Input before green revolution } & \multicolumn{2}{|c|}{ Input after green revolution } \\
\hline & $\begin{array}{l}\text { Practice } \\
\text { Local }\end{array}$ & Price & $\begin{array}{c}\text { Practice } \\
\text { Local and superior }\end{array}$ & Price \\
\hline Seed & Previous yields exchange seeds & 0 & Buy seed, previous yield & Rp.15,000/kg \\
\hline Fertilizers & Organic (cattle dung) & 0 & Synthetic & $2,500-4,000 / \mathrm{kg}$ \\
\hline Pesticide & Organic & 0 & Synthetic & $125,000 /$ season \\
\hline Weeding tools & Manual with hand & 0 & Herbicide & $15,000 /$ season \\
\hline Plowing tools & Hoe, cow & 0 & Hoe, tractor & $400,000 / 100$ bata \\
\hline Rice grinder & Lisung, gintiran & 0 & Grinder machine & $600 / \mathrm{kg} 1 \mathrm{Lier} / 10 \mathrm{~kg}$ beras \\
\hline Weight of grain & - & $10-15 \mathrm{~kg} / \mathrm{bata}$ & - & $5-6 \mathrm{~kg} / \mathrm{bata}$ \\
\hline Price & - & Rp.100,00/kg & - & Rp. $5000-5,500 / \mathrm{kg}$ \\
\hline
\end{tabular}

Note: 1 bata $=3.75$ m x 3.75 m; $1 \$$ USA= Rp.14,037.00

Table 2. Comparison of the rice production based on planting local rice and superior rice per season in 2019

\begin{tabular}{|c|c|c|c|c|}
\hline & \multicolumn{2}{|c|}{ Planting local rice } & \multicolumn{2}{|c|}{ Planting superior rice } \\
\hline & Practice & Price (Rp.) & Practice & Price (Rp) \\
\hline Seeds & $\begin{array}{l}\text { Previous yields } \\
\text { exchange seeds }\end{array}$ & Rp. 0 & $\begin{array}{l}\text { Purchased, } \\
\text { previous yield }\end{array}$ & Rp. 25000/kg \\
\hline Fertilizers & Synthetic & $\begin{array}{l}\text { Urea Rp. } 2500 / \mathrm{kg} \\
\text { NPK Rp.4000/kg }\end{array}$ & Synthetic & $\begin{array}{l}\text { Urea Rp. } 2500 / \mathrm{kg} \\
\text { NPK Rp.4000/kg }\end{array}$ \\
\hline Pesticide & Organic and Synthetic & $\begin{array}{l}\text { Surian Leaf (Toona sureni ) } \\
\text { and Korelat Rp. } 20.000 / \mathrm{kg}\end{array}$ & Synthetic & Kolerat Rp.20.000/kg \\
\hline Weeding tools & Herbicide & & Herbicide & \\
\hline Plowing tools & Hoe, Tractor & Rp.400.000/100 bata & Hoe, Tractor & Rp.400.000/100 bata \\
\hline Rice grinder & Grinder machine & $\begin{array}{l}\text { Rp. } 600 / \mathrm{kg} \\
1 \mathrm{~L} / 10 \mathrm{~kg} \text { rice }\end{array}$ & Grinder machine & $\begin{array}{l}\mathrm{Rp} .600 / \mathrm{kg} \\
1 \mathrm{~L} / 10 \mathrm{~kg} \text { rice }\end{array}$ \\
\hline Tax & & $\begin{array}{l}\text { Rp.100.000-Rp.150.000/100 } \\
\text { bata }\end{array}$ & & $\begin{array}{l}\text { Rp. } 100.000- \\
\text { Rp. } 150.000 / 100 \text { bata }\end{array}$ \\
\hline Grain yield per 100 bata & & $500 \mathrm{~kg}-800 \mathrm{~kg}$ & & $500 \mathrm{~kg}-600 \mathrm{~kg}$ \\
\hline Rice yield per $100 \mathrm{~kg}$ & & $\begin{array}{l}70 \mathrm{~kg} \text { from } 100 \mathrm{~kg} \text { grain } \\
350 \mathrm{~kg} \text { from } 500 \mathrm{~kg} \text { grain }\end{array}$ & & $\begin{array}{l}50 \mathrm{~kg} \text { from } 100 \mathrm{~kg} \text { grain } \\
250 \mathrm{~kg} \text { from } 500 \mathrm{~kg} \text { grain }\end{array}$ \\
\hline Grain price & & $5500-7000 / \mathrm{kg}$ & & $5000-6000 / \mathrm{kg}$ \\
\hline
\end{tabular}

Note: 1 US \$ = Rp.14.073,00; 1 bata $=3.75 \mathrm{~m} \times 3.75 \mathrm{~m}=14 \mathrm{~m}^{2}$ 


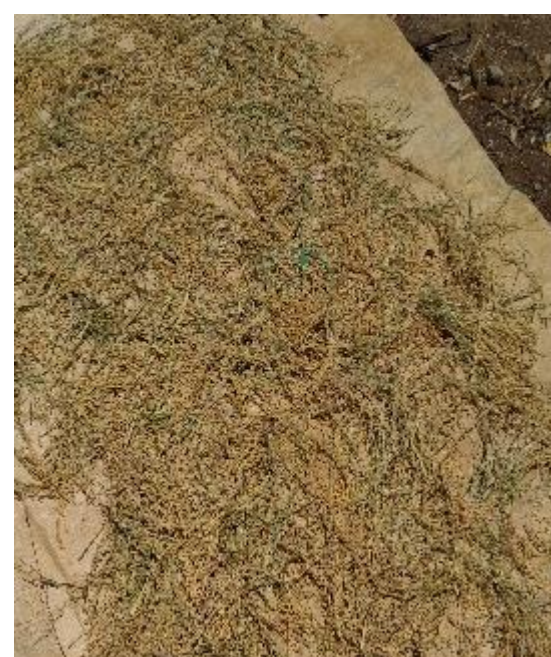

A

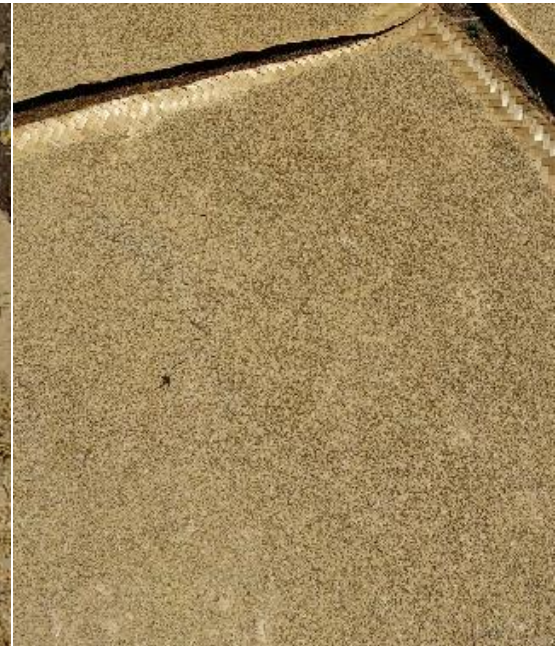

B

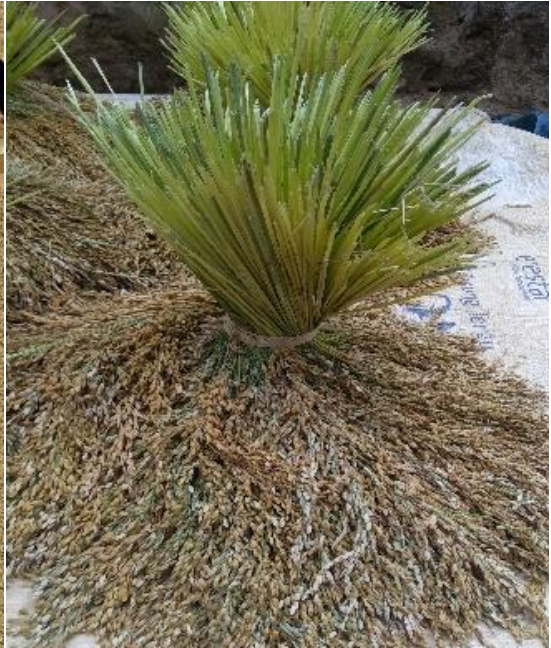

C

Figure 2. Local rice varieties currently cultivated: A. Ketan randa kaya, B. Mesir, C. Rayot

The difference in local rice production and superior rice can be seen from the grain obtained per 100 bata. In 100 bata planted with local rice, $500 \mathrm{~kg}-800 \mathrm{~kg}$ rice was obtained, while superior rice was only around $500-600 \mathrm{~kg}$. For every $100 \mathrm{~kg}$ of local paddy harvested, after processing, around $70 \mathrm{~kg}$ rice was obtained, while superior rice was only around $50 \mathrm{~kg}$. In addition, the selling price of local rice grain is also higher than superior rice. Rich local sticky rice types of rice can be sold at a price of Rp. 7,000 per kg or more. In addition, local rice, if stored, will last up to three seasons ( 1.5 years) while superior rice can only last a season if stored properly (cf. Iskandar and Ellen 1999). People have already realized that the yield from local rice is more and is profitable when compared to superior rice. However, many prefer superior rice because it can be harvested faster than local rice. They do not want to be left behind because if their rice is not harvested along with others, the birds and pests attack easily bringing loss of yields.

\section{Comparison of production based on land area}

Farmers in Sindang hamlet are divided into 3 groups based on land ownership, group A has less than 100 bata fields, group B has 100-200 bata fields, and group C has land area $>200$ bata. Table 3 shows the comparison of rice production based on area of land.

As many as $40 \%$ of respondents have an area of land less than 100 bata, 33\% of farmers have an area of rice fields ranging from 100 to $200 \mathrm{bata}$, and $27 \%$ have an area of more than 200 bata. Thus, the largest area of paddy fields owned by Sindang Hamlet farmers ranged from 30 to 70 bata. The smallest land area owned by farmers in the Sindang Hamlet is 30 bata, while the highest paddy field area is around 700 bata or 1 hectare $\left(9,800 \mathrm{~m}^{2}\right)$. As can be seen in the table, farmers with an area of less than 100 bata can produce $100-500 \mathrm{~kg}$. of rice grain. Farmers with a land area of 100-200 can produce about 1 to 2 tons of rice, while farmers with an area of over 200 bata can produce 2 to 5 tons of grain. The income mentioned is calculated by considering Rp.5500. as the average price of rice grain per kilo.

Table 3. Production based on the area of paddy fields n Sindang Hamlet, Rancakalong Village, Sumedang District, West Java, Indonesia in 2019

\begin{tabular}{llll}
\hline & $\begin{array}{l}\text { Land Area A } \\
\text { < 100 bata }\end{array}$ & $\begin{array}{l}\text { Land Area B } \\
\mathbf{1 0 0 - 2 0 0} \text { bata }\end{array}$ & $\begin{array}{l}\text { Land Area C } \\
\text { 200 bata }\end{array}$ \\
\hline Input & (Rupiah) & (Rupiah) & (Rupiah) \\
Fertilizers & $40,000-250,000$ & $170,000-350,000$ & $350,000-550,000$ \\
Pesticides & $20,000-100,000$ & $100,000-150,000$ & $200,000-350,000$ \\
Herbicide & $0-20,000$ & 50,000 & 150,000 \\
Tractor & 400,000 & $400,000-800,000$ & $800,000-2,800,000$ \\
Labor & $0-200,000$ & $75,000-400,000$ & $125,000-500,000$ \\
Grinder machine & $60,000-300,000$ & $500,000-600,000$ & $1,200,000$ \\
Tax & $55.000-150.000$ & $250,000-500,000$ & $600,000-1,700,000$ \\
Total Input C & $125,000-510,000$ & $1,200,000-1,600,000$ & $2,025,000-7,225,000$ \\
Weight of Grain & $100 \mathrm{~kg}-500 \mathrm{~kg}$ & $1,000 \mathrm{~kg}-2,000 \mathrm{~kg}$ & $2,000 \mathrm{~kg}-5,000 \mathrm{~kg}$ \\
Total Output R & $550,000-2,300,000$ & $5,500,000-11,000,000$ & $11,000,000-27,500,000$ \\
Profit & $1,790,000$ & 9.400 .000 & $20,275,000$ \\
R/C & 4,509 & 6,875 & 3,806 \\
\hline
\end{tabular}

Note: 1 US \$ = Rp.14,073.00 
$\mathrm{R} / \mathrm{C}$ values for land A (<100 bata), land B (100200bata) and $C$ (> 200 bata), is $4.50,6,87$ and 3.80 respectively (Table 3 ). This means that 1 rupiah of the input used has returned Rp.4.50 for group A, Rp. 6.87 for group $\mathrm{B}$, and 3.80 group C. According to Rahim et al. (2012), if the value of $\mathrm{R} / \mathrm{C}$ obtained exceeds 1 , such farming can be said to be economically feasible. Conversely, if the $\mathrm{R} / \mathrm{C}$ value is less than 1 , the farming can be said to be inappropriate. Therefore, when seen from the $\mathrm{R} / \mathrm{C}$ value, the farming system in Sindang Hamlet can be considered economically profitable because the $\mathrm{R} / \mathrm{C}$ value of each type of farm is greater than one $(\mathrm{R} / \mathrm{C}>1)$.

\section{The impact of rice production on environmental conditions}

Changes in rice production practices have an impact on the environment. The main cause is the use of synthetic fertilizers and pesticides which pollute water and soil. In addition, the dosage which continues to increase over time increases the amount of residue of hazardous chemicals in the environment. Excessive use of urea fertilizer will cause the soil to become dry and increase the need for water for paddy fields. The condition of the soil becomes less fertile and sour, so that the absorption of nutrients becomes hampered, and threatens the survival of organisms in the soil.

Excessive use of pesticides also affects the condition of pests. Pests will become resistant to pesticides, due to which farmers will increase the dosage of synthetic pesticides used. In addition, non-target animals that live in rice fields such as eels, tangas and rice snakes are harmed making them increasingly rare. Likewise, wild fish species and shellfish such as tutut that are often consumed by farmers, are reduced in number (Iskandar 2018).

Uneven planting patterns also affect the state of rice in Sindang Hamlet. Farmers who plant superior rice will usually harvest earlier, while farmers who plant local rice harvest later. This makes rice pests, such as rice-eating birds and brown planthopper, attack local rice because superior rice is no longer available. In addition to cropping patterns, the use of technology also has a negative impact on the environment. For example, the use of tractors as rice plower. Before the Green Revolution, Sindang hamlet farmers plowed their fields using cattle. In addition to saving energy, cattle also produce manure which will then become fertilizer for farmers' paddy fields. Meanwhile, the current use of tractors using gasoline as fuel, in addition to polluting the air, the gasoline residues also pollute the soil of rice fields.

Based on this study, it can be concluded that the Green Revolution program has caused various changes in the management system of rice farming in Sindang Hamlet. Before the Green Revolution program, Farmers practiced Low External Input and Sustainable Agriculture (LEISA) and Organic Farming System. Various inputs for rice farming were local rice seeds, organic fertilizers and local pesticides available in the village, and no need to pay/incur additional costs. LEISIA according to Reijntjes et al. (1992) include (i) Ensuring soil conditions that support plant growth, specifically by managing organic material and enhancing life in the soil; (ii) Optimizing the availability of balancing nutrient flows, specifically through nitrogen-fixing, nutrient pumping, and the use of external fertilizers as a compliment; (iii) Minimizing losses due to solar, air and water radiation by managing microclimate, water management, and erosion control; (iv) Minimizing the attack of pests and diseases against plants and animals through prevention and safe treatment; (v) Complementary and synergistic in the use of genetic resources which includes integration in integrated farming systems with a high level of functional diversity.

However, after the Green Revolution Program, residents of the village of Sindang Hamlet practiced a system with Height-External Input agriculture (HEIA) which depends on significant levels of artificial inputs, such as modern rice seeds, inorganic fertilizers, synthetic pesticides and fossil energy, which originate from outside the village and generally have to be purchased. This cultivation system has negative impacts on socio-economic and ecological factors.

\section{ACKNOWLEDGEMENTS}

The research was funded through the University Padjadjaran Lecturer Competency Research Grant Batch I No.3360/UN6.D/LT/2019, and is part of a research program of Dr. Ruhyat Partasasmita. The authors are thankful to the Rector of the University of Padjadjaran who has constituted RKDU (University Padjadjaran Lecturer Competency Research Grant). Thanks are also due to all those who contributed to this study, especially the local people of Dusun Sindang, Rancakalong Village, Sumedang, Indonesia for the information provided

\section{REFERENCES}

Albuquerque UP, Ramos MA, de Lucena RFP, Alencar NL. 2014. Methods and techniques used to collect ethnobiological data. In Albuquerque UP, Cruz da Cunha LF, Paiva de Lucena RF, Alves RRN (eds), Methods and techniques in ethnobiology and ethnoecology. Springer Science+ Business Media, New York.

Berkes F. 1999. Sacred Ecology. Routledge, New York.

Ellen RF, Harris H. 2000. Introduction. In: Ellen RF, Parkes P, Bicker A. (eds). Indigenous Environmental Knowledge and its Transformation: Critical Anthropological Perspective. Hardwood Academic Publishers, Amsterdam

Gliessman SR. 2007. Agroecology: The Ecology of sustainable food system. 2nd ed. CRC Press, New York.

Hidayat R.A, Partasasmita R, Iskandar J, Gunawan B. 2020. Changes in paddy field management in Sindang Hamlet, Rancakalong Village, Sumedang District, West Java, Indonesia. Biodiversitas 21: 98-105.

Iskandar J, Ellen R. 1999. In situ conservation of rice landraces among Baduy West Java. J Ethnobiol 19 (1): 97-125.

Iskandar J, Iskandar BS, Partasasmita R. 2018. Review: The impact of social and economic change on domesticated plant diversity with special reference to wet rice field and homegarden system farming of West Java, Indonesia. Biodiversitas 19 (2): 502-514.

Iskandar J, Iskandar BS. 2016. Ethnoastronomy the Baduy agricultural calendar and prediction of environmental perturbation. Biodiversitas 17 (2): 694-703.

Iskandar J. 2018. Ethnobiology, Ethnoecology and Sustainable Development. Plantaxia, Yogyakarta. [Indonesian] 
Lynch SJF, Hoelnsteiner RM, Cover CL. 1974. Data gathering by social survey. Philippine Social Science Council, Quezon City.

Newing H, Eagle CM, Puri RK, Watson CW. 2011. Conducting Research in Conservation: a Social Science Perspective. Routledge, London.

Partasasmita R, Iskandar BS, Nuraeni S, Iskandar J. 2019. Impact of the green revolution on the gender's role in wet rice farming: A case study in Karangwangi Village, Cianjur District, West Java, Indonesia. Biodiversitas 20: 23-36

Profile of Rancakalong Village, 2019

Rahim A, Supardi S, Hastuti DRD. 2012. Model of agricultural economic analysis. Penerbit Universitas Negeri Makassar. Makassar. [Indonesian]

Reijntjes C, Havekort, Waters-Bayer. 1992. Farming for the future: an introduction to low-external input and sustainable agriculture. The MacMillan Press Ltd, London.
Shiva V. 2016. Who really feeds the world?: the failures of agribusiness and the promise of agroecology. North Atlantic Books, California.

Warren DM, Slikkerveer LJ, Brokensha D. (eds). 1995. The Cultural Dimensions of Development: Indigenous Knowledge Systems. Intermediate Technology Publications, London.

Warsiti I. 2009. Management and utilization of local rice cultivars and factors affecting the sustainability of local rice cultivars. [Thesis] Program Master in Environmental Science, Universitas Padjadjaran, Bandung. [Indonesian]

Winarto, Yunita T. 2016. The food crisis and "misguided thinking" why does it continue? Yayasan Pustaka Obor Indonesia, Jakarta. [Indonesian]. 